\title{
A COMMONSENSE KNOWLEDGE SYSTEM BASED ON HUMAN CONSTITUENTS FOR DIAGNOSIS OF COVID-19
}

\author{
Dr. D.S. Kalana Mendis \\ Senior Lecturer \\ Department of Information Technology \\ Advanced Technological Institute, Dehiwala, Sri Lanka
}

\begin{abstract}
According Ayurvedic medical practices, a person is dominated on one of constitute type namely vata, pita or kapha. Important aspect of identification of constitute type is for diagnosis of diseases, because each of constituent type has a list of probable diseases. COVID-19 is depended on vata kapha constituent type. An important area of expertise for many physiologists is pathological assessment. At the initial stage commonsense knowledge based on human constituents is converted into a questionnaire. Removing dependencies among the questions are modelled using principal component analysis. Classification of the knowledge is processed through fuzzy logic module, which is constructed on the basis of principal components. A questionnaire has been used to capture commonsense knowledge of humans consisted of 72 questions pertaining to human constituents of vata, pita and kapha. A survey for $\mathbf{1 0 0}$ numbers of laymen for statistical modeling using the questionnaire has been conducted. Total of 25 principal components have been identified using SPSS. Possible diseases that can be happened due to predominated humeral constitution type have been observed. But system gives a chance of handling that part which enhances to measure the effect of minimum constitution type for a disease. Evaluation of commonsense knowledge system has shown $77 \%$ accuracy. The system has been reached the objectives of finding type of constituent. in percentages, dominant type of constituent for diagnosis of COVID-19.
\end{abstract}

Keywords- Ayurveda Medicine, Prakriti, COVID-19, pathological assessment, Commonsense knowledge systems

\section{INTRODUCTION}

Ayurvedic medicine has a very strong bearing on the concept of Prakurthi, which means nature (natural form) of the build and constitution of the human body $[2.12,13,14,15]$. According to Ayurveda the path to optimal health is different for people depending on their Prakruti. For individuals the Prakurthi, Dubey,G.P. [2] is defined as a combination of (Vatha, Pittha and Kapha). Vata contains the elements of Air (wind) and Ether
(Space). The qualities characterizing Vata reflect its elements. Pitta is made up of the elements of Fire and Water. Pitta qualities reflect those of its elements. Kapha is a combination of the elements Water and Earth. Kapha reflects the qualities of those elements. A balanced state of the Prakurthi makes a healthy and balanced person (Physically and mentally). Since we all have different combinations of the Prakurthi. The diagnosis of Prakruti offers unique insights into understanding and assessing one's health. It is not merely a diagnostic device but also a guide to action for good health. It assesses the, dominance of Prakurthi and gives advice for preventive and primitive health care. The ancient science of Ayurveda is the oldest known form of health care in the world. Important aspect of identification of constitute type is for diagnosis of diseases, because each of constituent type has a list of probable diseases, Dubey,G.P. [2] such as an important area of expertise for many physiologists is physiological assessment Seals, D. R. [10]. A balanced state of these factors leads to perfect health, and an imbalanced state of any one of these leads to illness.

\section{A. Concept of Epidemic Diseases in Ayurveda -}

Ayurvedic scholars and exponents of antiquity like Sushruta and Charaka recorded communicable and epidemic diseases in their works as aupasariga roga and janapadodhvansa repectively. The concept of janapadodhwamsa mentioned in Ayurveda refers to the situation where there is wide spread damage to environment as well as life forms. Janapadodhvansa literally means destruction or annihilation of communities or settlements. Epidemics and outbreaks of highly communicable diseases have blighted mankind since time immemorial, Bekal S, Hebbar V.J. [11].

\section{B. Diagnosis of COVID-19}

Dosa - type of constituent: Aggregation of Kapha Dooshya- Fever

Agni- Low digestion strength

Ama- Altered digestion and metabolism are evident Sroto-Respiratory tract 


\section{International Journal of Engineering Applied Sciences and Technology, 2020 \\ Vol. 5, Issue 4, ISSN No. 2455-2143, Pages 13-16 \\ Published Online August 2020 in IJEAST (http://www.ijeast.com)}

Sroto dusti prakara- Excessive flow

Symtoms exhibited area- Upper part of the body where Kapha is naturally dominant, Bekal S, Hebbar V.J. [11].

For the conditions affecting pranavasa srotas one has to adopt Shwasa Chikitsa- the treatment recommended for breathlessness and related disorders. Main emphasis should be given on Vata Kapha constituent type with an emphasis on Pitta constituent for diagnosis of COVID- 19. Recognition of human constituent in Ayurveda, is currently based on a standard questionnaire on subjective criteria based on ancient theories of Ayurvedic scholar Charaka, 1000 BC and Susruta, 600 BC [2,6] as a physiological assessment in clinical physiology. Questions in concerned are very much user-friendly and based on medical theories of Ayurveda, which is used for finding constituent type, has probes such as repeating questions and classification of constituent type and its possible diseases. This has been used for classification of individuals for many centuries. There has been no research into improve the questionnaire although people have realized that the classification is not acceptable sometimes. Using physiological assessment in clinical psychology has a problem of effective communication because of implicit knowledge for constructing Information systems ,Jonson, L. [1]. This complicates the effective communication of clinical data to the physiologist in support of clinical physiology.

\section{METHODOLOGY}

This section describes how one can use common sense knowledge system together with the corresponding fuzzy-expert system. Here we have considered Ayurvedic medicine domain, which uses tacit knowledge for identification of human constituents Mendis, D.S.K. et al. [7].

The main interface provides two modes as Developer and User. Suppose a person wants to find his constituents, he clicks on User. This brings the user to Analysis window that shows options to be entered by the user. Figure 1 shows data required for analysis of human constituents.

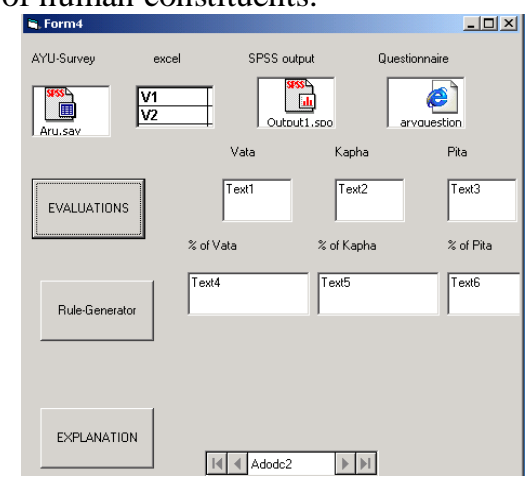

Figure 1. Data required for Analysis
User mode of the system facilitates the ordinary use of the system. For example, this mode provides an option for calling the questionnaire to be filled by the user. The questionnaire has been constructed with the help of XML documents. Here we take an example to show, how the user finds his constituents. By double clicking on the questionnaire icon in Figure 1, a user can open a questionnaire as shown in Figure 2.

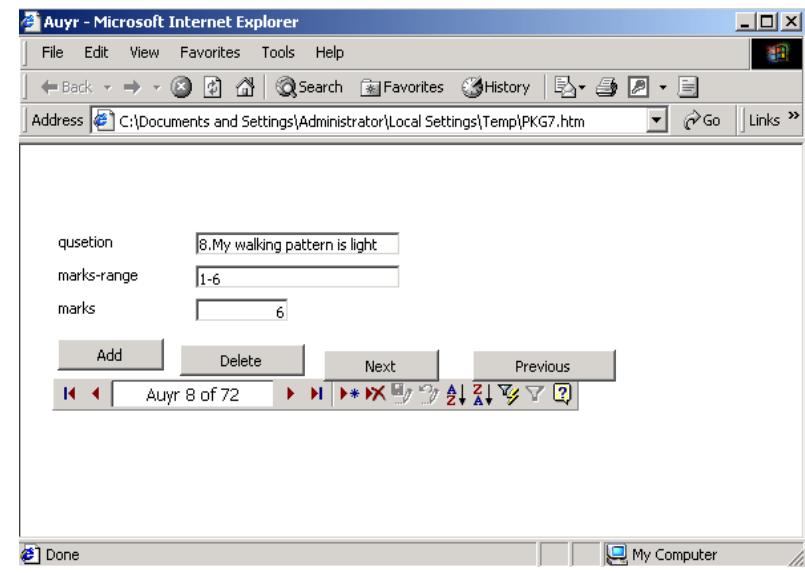

Figure 2. Questionnaire window

Having answered the questionnaire, user can press on the Evaluation button. Then the system shows the results of the analysis as shown in Figure 3. Note that system has shown percentage of the Vata, Kapha and Pita as the main result of the analysis. The percentage values show that constituents are fuzzy, but not exact.

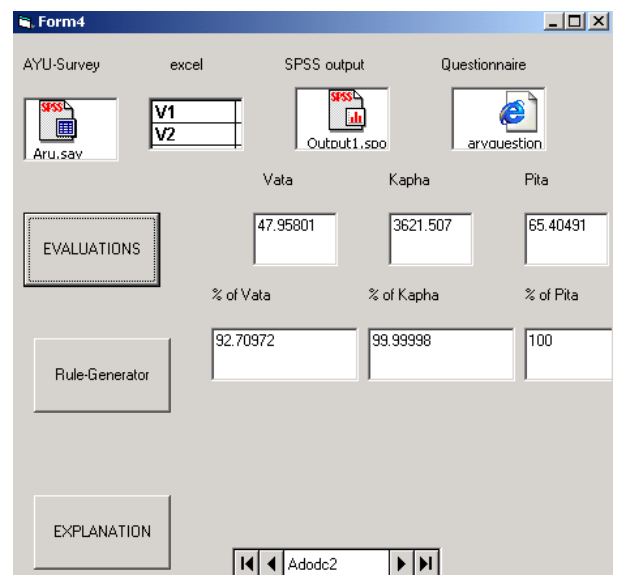

Figure 3. Results of the analysis

This analysis is done with the help of principal components analyser, Fuzzy logic module and the expert system. At this point the user can communicate with the expert system. 


\section{International Journal of Engineering Applied Sciences and Technology, 2020 \\ Vol. 5, Issue 4, ISSN No. 2455-2143, Pages 13-16 \\ Published Online August 2020 in IJEAST (http://www.ijeast.com)}

This gives three-phase knowledge modelling approach for modelling commonsense knowledge in, physiological assessment which enables holistic approach for clinical physiology to find:

- Type of dosa (constituent type:vata,pitta, kapha) in percentages

- Dominant type of dosa

- Possible disease based on type of dosa. COVID-19 is depended on Vata Kapha constituent type.

\section{RESULTS}

The system has been tested with the medical experts in the domain of Ayurvedic medicine, Mendis, D.S.K. et al. [7]. It was revealed that the system was able to identify human constituents approximating the classification by human experts in Ayurvedic medicine. Below is a justification for these results on the basis of three-phase framework that I have proposed.

\section{A. Removing dependencies}

The questionnaire used to capture commonsense knowledge of humans consists of 72 questions pertaining to constituents of vata, pita and kapha. We have done a pilot survey for 100 numbers of laymen for statistical modelling using the questionnaire. Principle component analyzer has been used to remove dependencies in the questionnaire. Chatfied, $d$, [3]. 25 principal components have been identified using SPSS as shown in matrix given below. Here V1, V2..V24, K1, k2..K24, $\mathrm{P} 1$, P2..P24 denotes question-numbering system in the questionnaire.

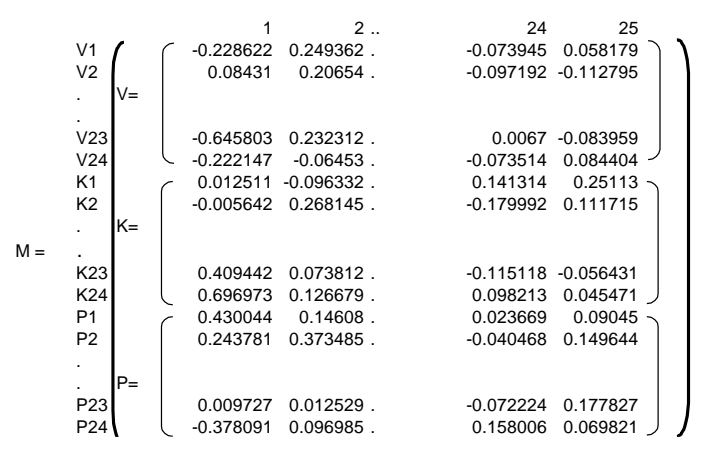

\section{B. Analysis of human constituents}

According to Ayurvedic medicine, human constituents can be computed into three categories as vata, pita and kapha, and percentages of these components are shown below. Note that the fuzzy membership functions for vata, pita and kapha have been constructed in fuzzy logic module using the out puts of principle component analyzer.

\section{Explanations for derived human constituents}

Explanations for output generated by the fuzzy logic module have been processed using fuzzy rules in the knowledge base of the expert system. The knowledge base has been implemented using FLEX expert system shell, which is embedded in WinProlog, Westwood, D. [4[. In relation to Ayurvedic domain, possible diseases can occur due to dominated constituent type.

\section{DISCUSSION}

Evaluation criterion has been set up as a comparison between the system and a real world expert in the similar domain. Both Ayurvedic expert and the system have been used to investigate human constitutions separately. It has been observed that only $77 \%$ of conclusions made by the sample have been emulated with both system and Ayurvedic expert. Difference of $23 \%$ has been shown due to model refinement process carried out by the Principal Component Analyzer. This leads to the reduction of the dependency among questions in the questionnaire. In normal consultancy process of classification of humeral constitutions, Ayurvedic expert may ask repeated questions by mistake due to large number of consultations. In current practice Ayurvedic expert can identify constitute type of a patient subjectively. But classifying constitutions type in percentages enhances the system. This leads to convince the fundamentals of Ayurveda according to classification of humeral constitutions. According to fundamentals of Ayurveda in classifying humeral constitution types, it has been stated that all constitutions types consists of a combination. Possible diseases that can be happened due to predominated humeral constitution type have been observed. But system gives a chance of handling that part which enhances to measure the effect of minimum constitution type for a disease.

\section{CONCLUSION}

The commonsense knowledge system in Ayurvedic medicine can be used for recognition of human constituents and its possible diseases. Commonsense knowledge modeling approach for modeling commonsense knowledge in, physiological assessment which enables holistic approach for diagnosis of COVID-19. The system has been reached the objectives of finding type of constituent (constituent type:vata,pitta, kapha) in percentages, dominant type of constituent and possible disease based on type of constituent. COVID-19 is depended on vata kapha constituent type.

It should be noted that with the help of Artificial Intelligence technologies I have improved the correctness of the decision making process in relation to the use of traditional questionnaire for pathological assessment for diagnosis of COVID-19 based on constituent type. This eliminates the inconsistencies and repetitiveness of answers and also provides a means for explanation of reasons for answers. Evaluation of the system has shown $77 \%$ accuracy. 


\section{International Journal of Engineering Applied Sciences and Technology, 2020 \\ Vol. 5, Issue 4, ISSN No. 2455-2143, Pages 13-16 \\ Published Online August 2020 in IJEAST (http://www.ijeast.com)}

\section{ACKNOWLEDGEMENT}

I must acknowledge Royal Asiatic Society of Sri Lanka, Sri Lanka Association for advancement of Science, SAARC Cultural Centre and Institute of Physics Sri Lanka for encouraging me to engage for a research culture.

\section{REFERENCE}

[1]. Jonson, L, (1988), Expert system Architectures, Kopan Page Limited.

[2]. Dubey,G.P, (1978), The Physiological concepts in Indian medicine, Science and Philosophy of Indian medicine, Shree Beldyanath Ayurved Bhawan Ltd.

[3]. Chatfied, d, (1996), Introduction to Multivariate Analysis", Chapman and Hall.

[4]. Westwood, D, (2002), Flex reference guide, LPA, U.K

[5]. Richards, D, Bush, P, (2003), Measuring, Formalizing and Modeling Tacit Knowledge, IEEE/Web Intelligence Conference (WI-2003) Bejing.

[6]. Tripathi, S.N, (1978), Clinical Diagnosis, Science and Philosophy of Indian medicine.

[7]. Mendis.,D.S.K., Karunananda A.S, Samarathunga, U. Ratnayake, U, (2017), An approach to the development of commonsense knowledge modelling systems for disaster, management, Artificial Intelligence Review, Vol 28, pp.179-196.

[8]. James, A. et al, (1983),.Reggia, Dana S. Nau and Pearl Y. Wang, Diag, "Diagnostic expert systems based on a set covering model", International Journal of Man-Machine Studies, Volume 19, Issue 5, pp. 437-460, 8

[9] Sugeno, M., (1985), Industrial applications of fuzzy control, Elsevier Science Pub. Co.

[10] Seals, D. R, (2013). Translational physiology: from molecules to public health. The Journal of physiology, 591(14), 3457-3469. https://doi.org/10.1113/iphysiol.2013.253195

[11] Bekal S, Hebbar VJ, CoronaVirus: Ayurvedic Analysis, Possible prevention, Treatment Principles, Remedies [Internet], India, https://www.easyayurveda.com, 2020 [cited 2020 April 22] Available from https://www.easyayurveda.com/2020/03/16/coronavirusayurveda-prevention-treatment
[12 Prasher B, et al, (2008), Whole Genome expression and biochemical correlates of extreme constitutional types defined in Ayurveda. J Transl Med. pp. 6:48.

[13] Bhushan, P, et al, (2005, Classification of human population based on HLA gene polymorphism and the concept of Prakriti in Ayurveda. J Altern Complement, pp. 349-53.

[14] Ghodke, Y, et al, (2009), Traditional Medicine to Modern Pharmacogenomics: Ayurveda Prakriti Type and CYP2C19 Gene Polymorphism Associated with the Metabolic Variability. Evid Based Complement Alternat.

[15] Govindaraj, P., Nizamuddin, S., Sharath, A. et al. Genome-wide analysis correlates Ayurveda Prakriti. Sci Rep 5, 15786 (2015). https://doi.org/10.1038/srep15786

\section{AUTHOR PROFILE}

D.S Kalana Mendis is a Senior lecturer at Department of Information Technology, Advanced Technological Institute, Dehiwala. He obtained BSc (Hons.) in Physical Sciences from University of Kelaniya, Sri Lanka. He obtained his MPhil (Computer Science) from Open University of Sri Lanka and obtained PhD (Fuzzy logic in Artificial Intelligence) from Open University of Sri Lanka. He is a Chartered Physicist. He has published more than 80 research publications and reviewed many research papers in IEEE Transaction of Fuzzy systems, Journal of Intelligent Information Management, International Conference on Advances in ICT for Emerging Regions, He received presidential research award for scientific research in 2014. He was a Chairman of Environment committee in Sri Lanka Association for Advancement of Sciences in 2017 and council member for Institute of Physics Sri Lanka in 2014. $\mathrm{He}$ is a Life member of Royal Asiatic Society of Sri Lanka. His research fields are fuzzy modeling, fuzzy sets and systems, health informatics and Artificial Intelligence in general. 